of guidance are being prepared. It is suggested that wherever possible sponsorship should be used to improve the scientific quality of meetings rather than to provide lavish social functions.

Council has approved an amendment to the Regulations which will allow Honorary Fellows to be elected at Quarterly Meetings [see this issue page 65] in order to avoid the potentially embarrassing situation where Honorary Fellows are elected at the Annual Meeting immediately before their formal admission to the College.

The Mental Deficiency Section have prepared a discussion document on some of the problems facing the specialty, and this document will be published in the Bulletin in the near future. [See this issue page 61].

The Court of Electors confirmed the results of the recent Preliminary Test and Membership Examination. There were 159 successful candidates in the Preliminary Test and 137 candidates passed the Membership. (Pass rates of 52 per cent and 55 per cent respectively.) The College understands that it is possible that the London Conjoint DPM may be phased out. The Court of Electors and other major College committees will consider whether there might be a place for a College Diploma in Psychiatry which would be suitable for candidates not wishing to become consultant psychiatrists in the NHS, or for other specialties, for example, general practitioners or geriatric physicians who might desire a qualification to confirm their knowledge and experience of psychiatric work.

A useful meeting of Secretaries of Divisions, Sections and Groups was held on 16 January, when arrangements to extend and co-ordinate activities were discussed.

Following the last meeting of Council, a discussion on Medical Audit was opened by Dr D. H. Dick, Director of the Health Advisory Service. A discussion paper on this important topic is being prepared for the Bulletin and it seems likely that this subject and all its ramifications will engage the attention of many College members in the next few years. The DHSS report 'Organizational and Management Problems of Mental Illness Hospitals' was published on 22 January. It is intended that this report should be discussed by Council at its next meeting, and it is hoped that the views of Divisions and Sections on the document will be forwarded in the course of the next few months.

Arrangements for the next Quarterly Meeting at Broadmoor Hospital on 6 and 7 May are virtually completed and the programme for the Annual Meeting is well in hand. Members' suggestions for topics and speakers for future meetings are always welcome and should be forwarded to me or to the Chairman or Secretary of the Programmes and Meetings Committee-now Drs Graham Lucas and Robin Murray. The College is grateful to these colleagues for the arrangements for the present Quarterly Meeting and for the excellent series of Maudsley Bequest lectures which they have organized.'

\title{
PART-TIME TRAINING IN PSYCHIATRY
}

The College and the Joint Committee on Higher Psychiatric Training have recently considered part-time training in psychiatry. Although it is recognized that it may not always be possible, it is recommended that the training period should include at least one year of full-time training, though this is not mandatory. The conditions for part-time training are set out under two headings:

(1) General Professional Training in Psychiatry and criteria for entry to the MRCPsych Examination.

(2) Higher Training in Psychiatry.

(1) Approved Training for the MRCPsych Examination (General Professional Training).

(a) Part-time training will be dealt with as an individual circumstance. The Court of Electors through the Dean, will consider each application separately.

(b) Training must be undertaken in an approved post. Supernumerary posts in an approved hospital or training scheme will be acceptable.

(c) The total training period should be equivalent in duration and quality to the normal whole-time training requirement. This does not mean that it is necessary to demand of part-time trainees that they should complete exactly the pro-rata length of training. (Allowance will be made for commitment to the specialty and the use of non-sessional time for such activities as reading and continuing study.)

(d) The Court of Electors, through the Dean, will allow credit for part-time training. This will usually not be less than half-time, though some periods of less than this may be allowed. Part-time training must include all types of clinical experience and responsibility, including residential, 'on-call' and emergency duties in all respects similar to the experience of those undertaking whole-time training, but on a pro-rata basis.

(e) The minimum duration of any one appointment should generally not be less than six months. If there is a break between periods of training, the length of training might need to be increased. This 
decision will rest with the Court of Electors, through the Dean.

(2) Higher Professional Training in Psychiatry. Part-time higher training is acceptable under the following conditions:

(a) Part-time training will be dealt with as an individual circumstance. The Joint Committee on Higher Psychiatric Training will consider each application separately.

(b) Training must be undertaken in posts approved by the Joint Committee in the Senior Registrar grade (or, exceptionally, other grades). Supernumerary appointments will be acceptable if approved by the Joint Committee.

(c) The total training period should be equivalent in duration and quality to the normal whole-time training requirement. This does not mean that it is necessary to demand of part-time trainees that they should complete exactly the pro-rata length of training. (Allowance can be be made for commitment to the specialty, and the use of non-sessional

\section{SUBSCRIPTIONS AND THE APPEAL}

Some overpayments of subscriptions occurred during 1979 mainly because members' banks failed to cancel old standing orders. Instead of agreeing to have a refund some members donated the excess to the Appeal Fund. I am delighted to find that the total of these sundry donations is nearly $£ 900$, and on behalf of the College I would like to thank everyone concerned for their generosity. A few of the members who have reached $\mathbf{4 0}$ years membership of the College and the RMPA kindly agreed to divert their annual subscription payments to the Appeal Fund, and I should like to extend to them my gratitude for this action.

Just recently one of the Divisions donated the surplus from its Conference to the Appeal which amounted to almost $£ 200$. This kind of zeal is very satisfying, but we still need your support, and early in 1980 the Appeal Committee will probably be looking at other ways of raising money in an effort to establish a fairly regular income so that individual projects can be considered annually and, if financially viable, embarked upon.

A covenanted donation of $£ 10$ a year from just 500 members would net $£ 7,500$ annually with the Income Tax refund which the College can claim. There is a loose-leaf Deed of Covenant form in this issue. Why not fill it in now and make 1980 the year of the College?

C. M. B. PARE, Honorary Treasurer time for such activities as reading and continuing study.)

(d) Part-time higher training should not ordinarily be less than half-time. Higher fractions would be acceptable and the total period of training would be adjusted accordingly at the discretion of the Joint Committee. Part-time higher training must include clinical experience and responsibilities, administrative duties, teaching responsibilities towards junior trainees, training in necessary special techniques with Consultant supervision, and opportunities for research in all respects similar to the experience of those undertaking whole-time higher training. It should also include the same or similar resident and 'on-call' commitments as those for full-time trainees, but on a prorata basis.

DESMOND POND, President: Royal College of Psychiatrists

KENNETH RAWNSLEY, Chairman: Joint Committee on Higher Psychiatric Training

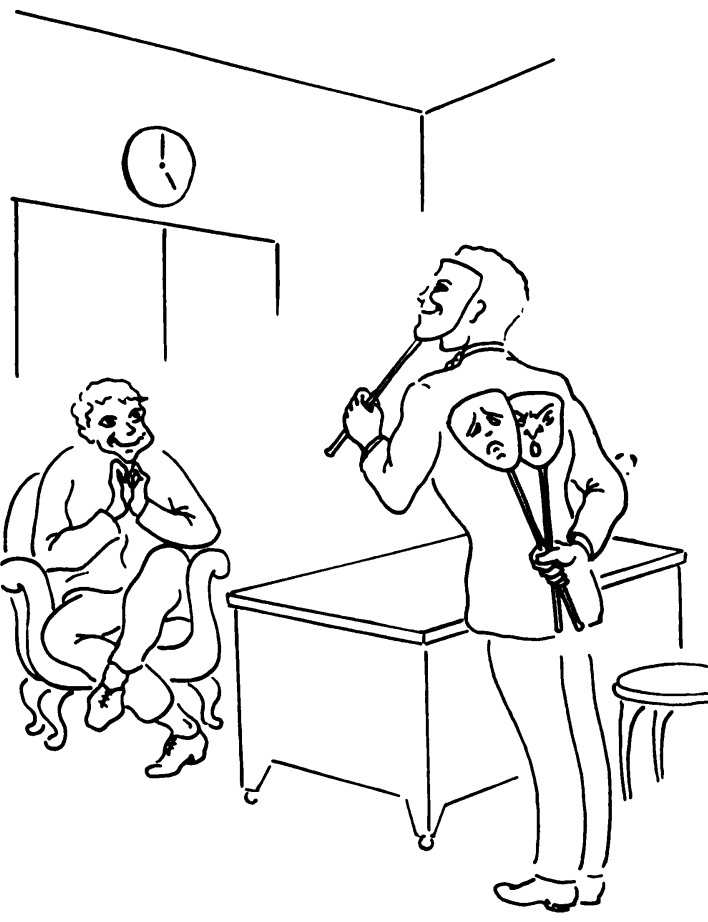

Psychiatrists at Work: Psychotherapy.

R. de Alarcon 